\title{
ESTIMATION OF BIOMASS AND CARBON POOL IN BARKOT FOREST RANGE, UK USING GEOSPATIAL TOOLS
}

\author{
Priti Attri ${ }^{1, *}$ and S. P. S. Kushwaha ${ }^{2}$ \\ ${ }^{1}$ Haryana Space Applications Centre - HARSAC Node, Department of Science \& Technology, Haryana, India - \\ pritiattri8@gmail.com \\ ${ }^{2}$ Indian Institute of Remote Sensing, Indian Space Research Organization, Dehradun, India
}

Commission V, SS: Natural Resources Management

KEYWORDS: Biomass, Growing stock, Carbon, NDVI, Shorea robusta, Tectona grandis

\begin{abstract}
:
The forest ecosystem is an important carbon sink and source containing majority of the aboveground terrestrial organic carbon. Carbon management in forests is the global concern to mitigate the increased concentration of green house gases in the atmosphere. The present study estimated vegetation carbon pool and biophysical spectral modelling to correlate biomass with reflectance/ derivatives in Barkot Forest Range, Uttarakhand. The study was carried out using Cartosat-1, IRS-P6 LISS-IV MX, IRS LISS-III, Landsat 7 ETM satellite data and ground data collected from stratified random sampling. Forest type and forest crown density was mapped using resolution merged Cartosat-1 and LISS-IV imagery. Growing stock, biomass and carbon was calculated for the individual sample plots using inventory-based biomass assessment technique. Field-inventoried data was correlated with the surface reflectance and derivatives of it. Among the four vegetation types, viz. Shorea robusta, S. robusta mixed, S. robusta Tectona grandis mixed, T. grandis plantation, mixed plantation, Grassland and Agriculture/ orchard, the S.robusta was found to be the dominant vegetation in the area, covering $55.86 \mathrm{~km}^{2}$ of the total area. The study revealed that the S.robusta with high density had the highest aboveground biomass (AGB) ( $\mathrm{t} / \mathrm{ha}$ ) was found in S.robusta $>70 \%\left(530 \mathrm{t} \mathrm{ha}^{-1}\right)$, followed by S.robusta $40-70 \%\left(486 \mathrm{tha}^{-1}\right)$ and minimum was found in mixed plantation $<10 \%\left(101 \mathrm{tha}^{-1}\right)$. The general trend showed the decrease in AGB with decrease of forest density in each forest type category. The average AGB of $S$. robusta T. grandis forest was found ( $\left.308 \mathrm{t} \mathrm{ha}^{-1}-458 \mathrm{t} \mathrm{ha}^{-1}\right)$ due to the dominancy of S.robusta trees. The study highlighted the invaluable role of geospatial technology and field inventory for growing stock, biomass and carbon assessment.
\end{abstract}

\section{INTRODUCTION}

Forests play an important role in stabilizing the atmospheric concentration of $\mathrm{CO}_{2}$ as they can be both sinks and sources of carbon depending upon the succession, disturbances and management practices. It is estimated that 2-4 Gt $\mathrm{C}$ of atmospheric carbon can be sequestered by forests annually (Lu et al. 2010; Qureshi et al. 2012). Forests contain about $50 \%$ of the world's terrestrial organic carbon stocks, and forest biomass constitutes about $80 \%$ of terrestrial biomass. Forests also contribute over two thirds of global terrestrial net primary production. Each year, forests lock up 335-365 $\mathrm{Gt}$ of carbon making them a viable solution to climate change mitigation (MEA, 2005). Tropical forests store roughly $475 \mathrm{Bt}$ of carbon (Pan et al. 2011). Retaining this carbon through conservation and increasing its stock through management activities, promote forest growth that will play a major role in curbing the $\mathrm{CO}_{2}$ concentration in atmosphere (Valentin B. and Sebastiaan L., 2015).

Increasing temperatures, longer dry seasons and increasing $\mathrm{CO}_{2}$ concentrations in the atmosphere in the long term, are expected to reduce the capacity of forests to store and sequester carbon, possibly converting forests from carbon sinks to carbon sources (Whitehead, D., 2011; Ollinger et al. 2008). The potential impacts of climate on forests vary according to geographical region and local topography and land uses, but with only a few exceptions, temperature is expected to increase (FAO, 2012). Remote sensing has opened an effective way to estimate forest biomass and carbon (Liviu et al. 2017, Galidaki et al. 2016). According to

${ }^{*}$ Corresponding author the IPCC GPG (Intergovernmental Panel on Climate Change, Good Practice Guidance), remote sensing methods are especially suitable for verifying the national LULUCF (Land Use, Land-Use Change, and Forestry) carbon pool estimates-particularly the aboveground biomass (IPCC, 2007). Remote sensing and GIS technologies have become essential for forest planning and management. Major contributions of these technologies in forestry sector in India are: forest cover mapping, growing stock/timber volume assessment, encroachment detection and forest development planning, wildlife habitat evaluation, grassland mapping, and environmental impact assessment (Kushwaha, 2005, Nandy et al. 2017).

Over the past 25 years global carbon stocks in forest biomass have decreased by almost 11 gigatonnes (Gt). This reduction has been mainly driven by conversion to other land uses and to a lesser extent by forest degradation (FRA, 2015). In 2010, the total biomass (aboveground and belowground) contained in the world's forests amounted to $600 \mathrm{Gt}$, the total carbon stock in the biomass of the world's forests is estimated at $289 \mathrm{Gt}$ and total carbon stock in dead wood and litter in 2010, amounted to $72 \mathrm{Bt}$ or 17.8 tha $^{-1}$ (FAO, 2010). The total growing stock of India's forest and trees outside forests is estimated as 5,822.37 million cum (FSI, 2017).

Some of the commonly employed techniques to estimate forest biomass are (i) the harvest of average size trees either for the stand or within given size classes, (ii) the harvest of all materials in an unit area, and (iii) the harvest of individuals over a wide range in size and establishing the relationship between biomass and easily measurable plant parameters such as diameter and/or height. The height- 
diameter at breast height (dbh) relationship to biomass in forest stand is well formulated (Kira and Ogawa, 1971). Kushwaha et al. (2003) have found that the satellite imagebased inventory using stratified random sampling was found to have about $90 \%$ correspondence with the inventory done by the Forest Department in Lachchhiwala Forest Range, Uttarakhand. Remote sensing technology provides an important approach for estimating aboveground biomass (AGB) at large spatial scales (Pedro et al. 2017; Dube et al. 2016). Fern et al. (2018) evaluated the suitability of the normalized difference vegetation index (NDVI) and Optimized Soil Adjusted Vegetation Index (OSAVI) as potential estimators of green and vegetative coverage in a semi-arid rangeland. John et al. (2018) found that the vegetation indices calculated from wavelengths located in the red edge are good estimators of grassland biomass. Growing stock and biomass of woody vegetation in AsolaBhati Wildlife Sanctuary estimated with high accuracy using optical remote sensing data (Kushwaha et al. 2014). Growing stock estimated leads to quantification of biomass, which in turn is essential to assess the amount of carbon stored in the forests. The allometric equation for aboveground live tree biomass (AGB) by combining field-based, combination of field data observation and technology (WV-3 and light detection and ranging (lidar)) and by using only technology derivation (Mohd Zaki et al. 2018). The estimation of growing stock has, therefore, assumed significance existing climate change scenario. The present study attempts to couple ground based vegetation quantification with the satellite remote sensing

\section{STUDY AREA}

Barkot Forest Range $\left(30^{\circ} 03^{\prime} 52^{\prime}\right.$ '- $30^{\circ} 10^{\prime} 43^{\prime \prime} \mathrm{N}$ and $78^{0} 09^{\prime} 49^{\prime \prime}$ - 78017'09” E) lies about $40 \mathrm{~km}$ away from Dehradun, on the Dehradun-Rishikesh road (Fig.1). It consists of two adjacent forest ranges of Barkot and Rishikesh, covering an area of $84.96 \mathrm{~km}^{2}$. Forest type is Sal Mixed Moist Deciduous Forest. The forest is bounded in the north by Thano Forest Range, in the south by Motichur Forest Range, in the west by Lachchhiwala Forest Range and Song River and in the east by the river Ganga. The main nearby township are Doiwala, Bhaniawala and Rishikesh.

The whole area possesses the relatively flat, gentle and undulating topography. The altitude ranges between $340 \mathrm{~m}$ to $560 \mathrm{~m}$ above mean sea level. The study area lies in the Doon Valley. The soil is fine Loamy Thermic Haplustalf occurs on gentle sloppy terrain of study area (Working Plan of Dehradun Forest Division, 2009). The climatic condition of the study area is more temperate and humid than that of the adjoining districts. The temperature varies from $2{ }^{\circ} \mathrm{C}$ in January to about $42^{\circ} \mathrm{C}$ in June. Frost is common in winter, especially becomes severe from mid-December to midFebruary, causing damage to young $S$. robusta regeneration.

The major portion of the forests in Dehradun Forest division comprise of Sal, classified under the three sub-types viz; Moist Shiwalik Sal Forest, Moist Bhabhar Dun Sal Forest and Dry Shiwalik Sal Forest. The study area Brakot Forest range lies within Sub-Group 3C North Indian Tropical Moist Deciduous Forests. Forest type is 3C/C2b Moist Bhabar Dun Sal Forest. Sal (Shorea robusta) is the dominant species, forming nearly pure stands. Its typical associates are sain (Terminalia tomentosa) and dhauri (Lagerstroemia parviflora). Other important associates are bahera (Terminalia belerica) and jamun (Syzygium cumini) in varying proportions.

The underwood is generally light and consists of rohini (Mallotus philippensis), chamror (Ehretia laevis) and amaltas (Cassia fistula). The undergrowth consists of karaunda (Carissa opaca), bindu (Colebrookia oppositifolia), gandhela (Murraya koenigii), Ageratum cnyzoids etc. The common grasses are pula (Imperata cylindrica) and baib (Eucaliopsis-binata). T. grandis of Verbenaceae was introduced on trial basis in 1955 but it was raised as commercial plantations since 1962 in Dehradun Forest Division. Most of the T. grandis plantations were raised by under planting in $S$. robusta areas of Barkot, Lachcchiwala and Rishikesh ranges where, S. robusta is in predominant stage.

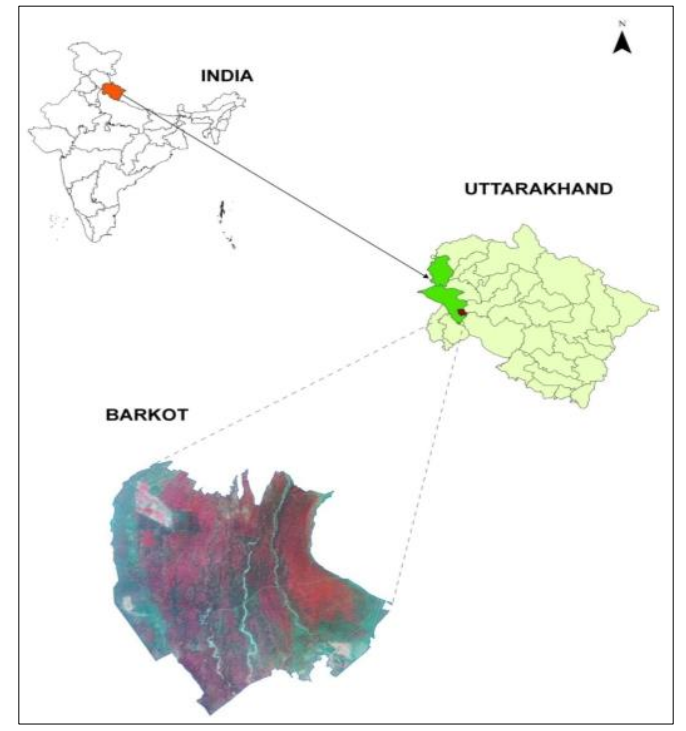

Fig. 1 Location of Barkot Forest Range in India

\section{MATERIALS AND METHODS}

The IRS-P6 LISS-IV MX (dated 16th March 2010), IRS-P6 LISS III (dated 22 ${ }^{\text {nd }}$ Jan. 2011) and Cartosat-1 PAN (dated $6^{\text {th }}$ March 2010) satellite imagery, with spatial resolution of $5.8,23.5$ and $2.5 \mathrm{~m}$ respectively, were used in the study. Radiometric correction and haze in satellite data was minimized using dark pixel subtraction technique (Lillesand et al. 2007), followed by geo-referencing using Landsat TM ortho-rectified image as reference image (Fig. 2). LISS-IV and Cartosat-1 datasets were merged using High Pass Filtering (HPF) resolution merge technique to obtain $2.5 \mathrm{~m}$ resolution false colour composite (FCC) of the study area (Fig. 3a). Preliminary interpretation of resolution merged Cartosat-1 and LISS-IV MX imagery was done for forest cover/landuse mapping of the study area by visual interpretation method. The normalized difference vegetation index (NDVI) image was used for forest canopy density stratification. 


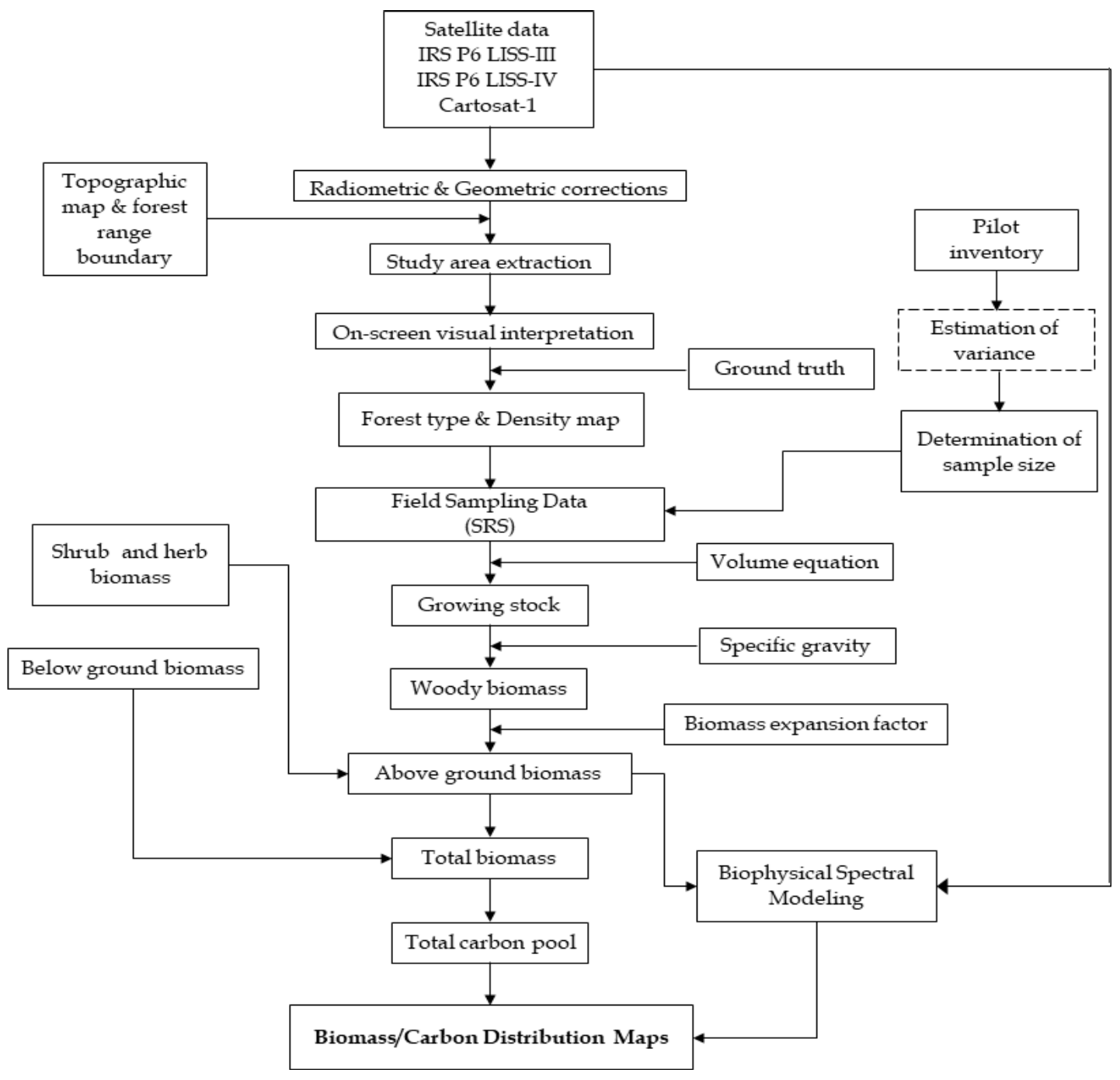

Fig. 2 The methodology

Both forest type and canopy density maps were validated in the field. A total of 125 ground truth points were used for interpretation. Forest type and canopy density maps were intersected to generate the type-density map and 187 points were used for accuracy assessment of the forest type-density map. The following formula (Chako, 1965) was used for calculating the number of plots required for sampling:

$$
\mathrm{n}=\frac{\left(\mathrm{t}^{2}\right) \times(\mathrm{CV})^{2}}{(\mathrm{SE} \%)^{2}}
$$

Where $\mathrm{n}$ is the number of sample plots, $\mathrm{t}$ is the statistical value at $95 \%$ significance level, $\mathrm{CV}$ is the coefficient of variation and $\mathrm{SE} \%$ is the standard error percentage. By using the above formula, a total of 43 plots of dimension $31.62 \mathrm{~m}$ x $31.62 \mathrm{~m}(0.1 \mathrm{ha})$ were laid for inventory of trees. Two plots of dimension $5 \mathrm{~m} \times 5 \mathrm{~m}$ were laid within each 0.1 ha plot in two opposite corners for shrub sample collection and four sample plots of dimension $1 \mathrm{~m} \times 1 \mathrm{~m}$ were laid within each 0.1 ha plot in each corner for litter collection. The sample plots were proportionally allocated to various strata following Cochran (1963):

$$
\mathrm{n}_{\mathrm{h}}=\frac{\mathrm{N}_{\mathrm{h}}}{\mathrm{N}} \times \mathrm{n}
$$

Where, nh is the no. of sample in h stratum, $\mathrm{Nh}$ is size of $\mathrm{h}$ stratum, $\mathrm{N}$ is total population size and $\mathrm{n}$ is total no. of samples. The following formula was used for determining sampling intensity (Cochran (1963) :

$$
\text { Sampling intensity }(\%)=\frac{\text { plot size } \times \text { sampling size }}{\text { total population size }} \times 100
$$

Field inventory was carried out for recording of all details regarding coordinates of sample plot, altitude, tonal characteristics on FCC, forest type, top canopy species, ground cover, soil type, terrain, local names of tress, circumference at breast height ( $\mathrm{cbh}$ ) at $1.37 \mathrm{~m}$ above ground etc. and the database in the prescribed format was systematically generated. GARMIN Juno SB GPS was used for recording coordinates in the middle of all the sampled plots. Shrub and herbaceous layer were clipped from sample plot and oven dried in laboratory to estimate total aboveground biomass. The litter was collected and fresh weight was taken and representative portion oven dried in laboratory for dry weight analysis. Volume of each tree was calculated using volumetric equations developed and compiled by FSI (1996). The sum of tree, shrub, herb, litter and humus layer biomass ( $\mathrm{t} / \mathrm{ha}$ ) was taken as total AGB of the plot and strata-wise. The BGB of trees was estimated by 
indirect method using root/shoot ratio available from existing studies. The R/S ratio of 0.30 for $S$. robusta trees (Negi, 1984) and 0.26 for other tree species (Cairns et al. 1997) were used. No estimates for shrubs and herbs layer for BGB were made due to non-availability of root/shoot ratio. The multiplication of biomass with the conversion factor of 0.47 represents the average carbon content in biomass (Westlake, 1963). Ground data was correlated with the surface reflectance and derivatives of multi-resolution data. The best correlation of aboveground biomass with NDVI was used for mapping aboveground biomass and carbon.

\section{RESULTS AND DISCUSSION}

The total forest area was accounted to $94 \%\left(79.54 \mathrm{~km}^{2}\right)$ of the total area (Table 1). S. robusta was found dominant in the area followed by mixed plantation, $T$. grandis and $S$. robusta mixed. S. robusta covers maximum area of 55.86 $\mathrm{km}^{2}$, followed by mixed plantations $\left(13.15 \mathrm{~km}^{2}\right), T$. grandis plantation $\left(5.32 \mathrm{~km}^{2}\right), S$. robusta $T$. grandis mixed $(1.87$ $\left.\mathrm{km}^{2}\right)$ and $S$. robusta mixed forest type $\left(3.34 \mathrm{~km}^{2}\right)$. In some areas, $S$. robusta is mixed with natural local forest species like Lagerstroemia parviflora, Syzygium cumini, Diospyros malabarica, Pterospermum acerifolium, Terminalia belerica, Mallotus phillipinensis, Cassia fistula, Ehretia laevis and Murraya koenigii. Fig. $3 \mathrm{~b} \& 3 \mathrm{c}$ shows forest land use and forest canopy density map of the study area. Among forest categories, dense forest dominates (39\%) the study area. Fig. 3d shows the forest type-density map of the study area, depicting fourteen forest type-density categories of $S$ robusta, $T$. grandis and mixed plantation.

The average AGB ranged from $101 \mathrm{t} \mathrm{ha}^{-1}$ (mixed plantation) to $530 \mathrm{t} \mathrm{ha}^{-1}$ (S. robusta). Sal forest had highest biomass due to higher value of specific gravity (0.72). Negi (1984) reported that the root biomass of sal trees increased with increasing $\mathrm{AGB}$, but the percentage contribution of $\mathrm{BGB}$ decreased from $38 \%$ to $22 \%$ with increasing diameter and AGB. Similar results were also reported by Misra (1969) for $S$. robusta tress. In the present study, the mean R/S $(0.30)$ for $S$. robusta tree was taken as per findings of Negi (1984) while, 0.26 was considered for other tree species.

The very high density of $S$. robusta forest had the highes mean volume i.e. $626.67 \mathrm{~m}^{3} / \mathrm{ha}$, while open density of mixed plantation the least $\left(104.72 \mathrm{~m}^{3} / \mathrm{ha}\right)$. The $S$. robusta forest with very high density contained maximum mean total biomass, i.e. $530.08 \mathrm{t} \mathrm{ha}^{-1}$, and mixed plantation with open density had the lowest, i.e. $101.34 \mathrm{t} / \mathrm{ha}$. The trend of total vegetation $\mathrm{C}$ in different forest strata was similar to tree layer, being the major contribution of tree layer in total vegetation carbon. The vegetation C-density $\left(249.14 \mathrm{t} \mathrm{ha}^{-1}\right)$ of $S$. robusta $(>70 \%)$, was found highest among all strata (Table 2). The present results support to the earlier studies by Negi and Chauhan (2002) on the total vegetation in $S$ robusta forest of Doon valley.
The reported C-density in total biomass varied from $72 \mathrm{t} \mathrm{ha}^{-1}$ to $320 \mathrm{t} \mathrm{ha}^{-1}$, depending upon density of different forest type classes. Based on the data on growing stock and total area of $S$. robusta forest in India, Lal and Singh (2003) reported $430.51 \mathrm{t} \mathrm{ha}^{-1}$ average above ground biomass of tree layer. Similar results have been reported by Negi and Chauhan (2002), Dadhwal et al. (2006) and Srivastava (2009). The above ground biomass of $S$. robusta forests reported with density classes are $136.2 \mathrm{t} \mathrm{ha}^{-1}$ for $0-40 \%$ class, $247.7 \mathrm{t} \mathrm{ha}^{-1}$ for $40-70 \%$ class and $351.5 \mathrm{t} \mathrm{ha}^{-1}$ for $>70 \%$ class density (Dadhwal et al. 2006). Srivastava (2009) also reported similar results in Barkot Forest range same of the present study area. Similar results have been reported by Pandey et al. (2010), Singh S. (2010) and Anonymous (2009). The above ground biomass of $S$. robusta forests was reported within the range of $116 \mathrm{t} \mathrm{ha}^{-1}$ to $520 \mathrm{t} \mathrm{ha}^{-1}, S$. robusta mixed (230 $\left.\mathrm{t} \mathrm{ha}^{-1}-519 \mathrm{t} \mathrm{ha}^{-1}\right)$, mixed forest $\left(45-228 \mathrm{t} \mathrm{ha}^{-1}\right)$, and $T$. grandis plantation $\left(63-410 \mathrm{t} \mathrm{ha}^{-1}\right)$ under different density classes (Pandey et al. 2010). Singh (2010) also reported $138.21 \mathrm{t} \mathrm{ha}^{-1}$ to $461.33 \mathrm{t} \mathrm{ha}^{-1}$ AGB in $S$. robusta forest, $221 \mathrm{t}$ $\mathrm{ha}^{-1}$ to $261 \mathrm{t} \mathrm{ha}^{-1}$ in $S$. robusta $T$. grandis mixed under different density classes.

Table 1 Area under forest type-density strata.

\begin{tabular}{|c|c|c|c|}
\hline $\begin{array}{l}\text { Sr. } \\
\text { No. }\end{array}$ & Forest type-density class & $\begin{array}{l}\text { Area } \\
\left(\mathrm{km}^{2}\right)\end{array}$ & $\begin{array}{l}\text { Area } \\
(\%)\end{array}$ \\
\hline 1. & S.robusta $(>70 \%)$ & 25.11 & 31.56 \\
\hline 2. & S.robusta $(40-70 \%)$ & 20.36 & 25.60 \\
\hline 3. & S.robusta $(10-40 \%)$ & 9.47 & 11.91 \\
\hline 4. & S.robusta $(<10 \%)$ & 0.96 & 1.21 \\
\hline 5. & $\begin{array}{l}\text { S.robusta mixed (40- } \\
70 \%)\end{array}$ & 3.33 & 4.19 \\
\hline 6. & $\begin{array}{l}\text { S.robusta T. grandis } \\
(>70 \%)\end{array}$ & 0.10 & 0.13 \\
\hline 7. & $\begin{array}{l}\text { S.robusta T. grandis } \\
(40-70 \%)\end{array}$ & 1.70 & 2.14 \\
\hline 8. & $\begin{array}{l}\text { S.robusta T. grandis } \\
(10-40 \%)\end{array}$ & 0.06 & 0.08 \\
\hline 9. & T. grandis $(40-70 \%)$ & 2.42 & 3.05 \\
\hline 10. & T. grandis $(10-40 \%)$ & 2.04 & 2.57 \\
\hline 11. & T. grandis $(<10 \%)$ & 0.84 & 1.06 \\
\hline 12. & $\begin{array}{l}\text { Mixed plantation (40- } \\
70 \%)\end{array}$ & 4.03 & 5.07 \\
\hline 13. & $\begin{array}{l}\text { Mixed plantation }(10- \\
40 \%)\end{array}$ & 4.87 & 6.13 \\
\hline 14. & $\begin{array}{l}\text { Mixed plantation } \\
(<10 \%)\end{array}$ & 4.23 & 5.32 \\
\hline & Total & 79.54 & 100.00 \\
\hline
\end{tabular}


ISPRS Annals of the Photogrammetry, Remote Sensing and Spatial Information Sciences, Volume IV-5, 2018 ISPRS TC V Mid-term Symposium “Geospatial Technology - Pixel to People”, 20-23 November 2018, Dehradun, India

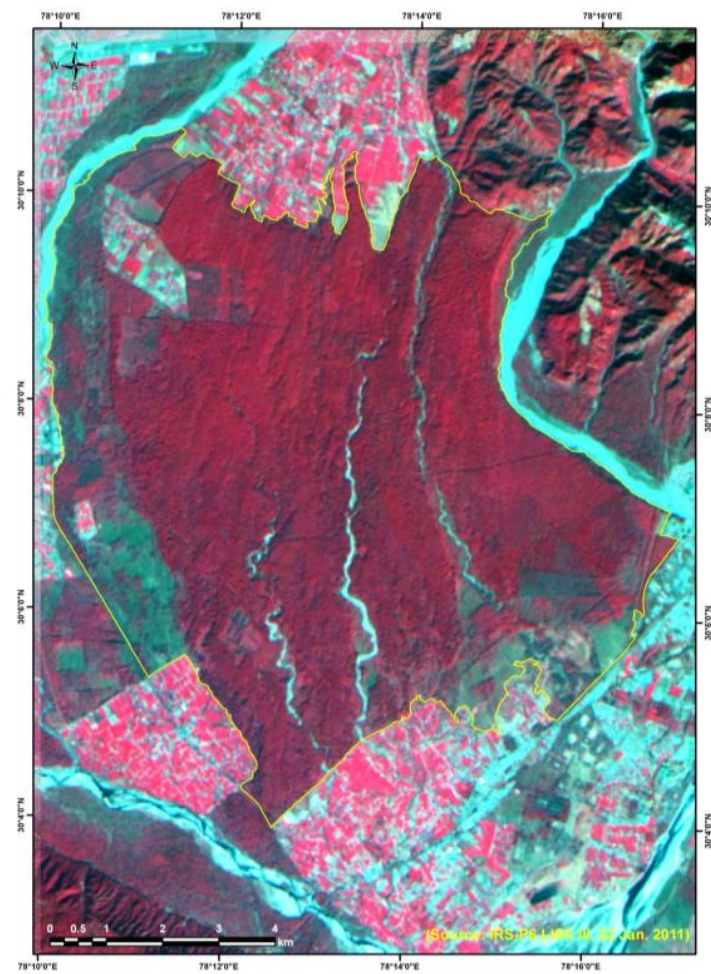

(a)

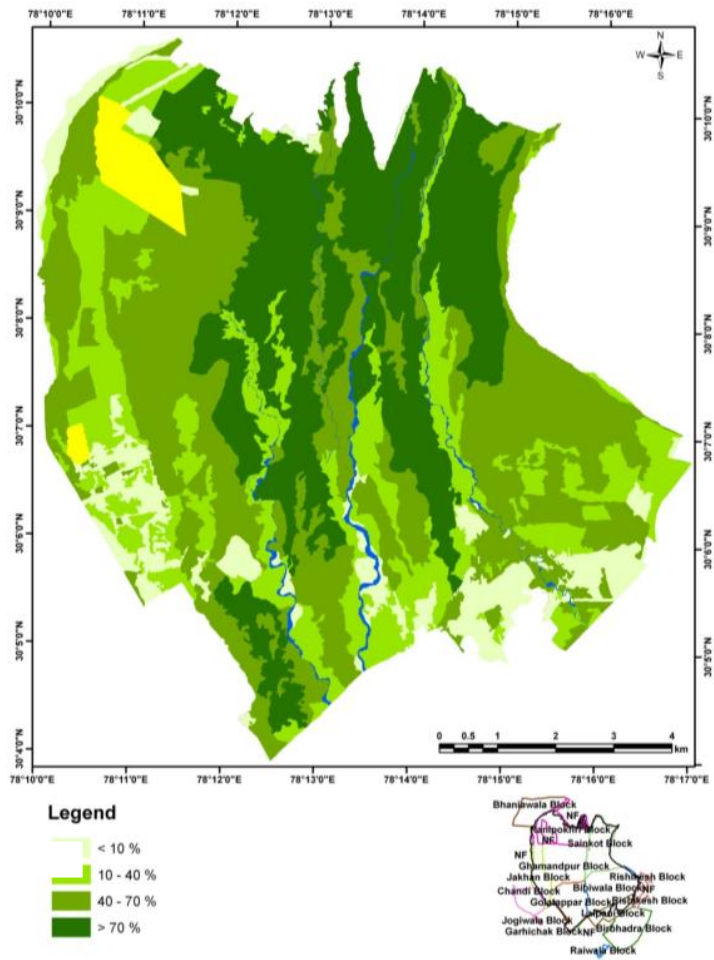

(c)

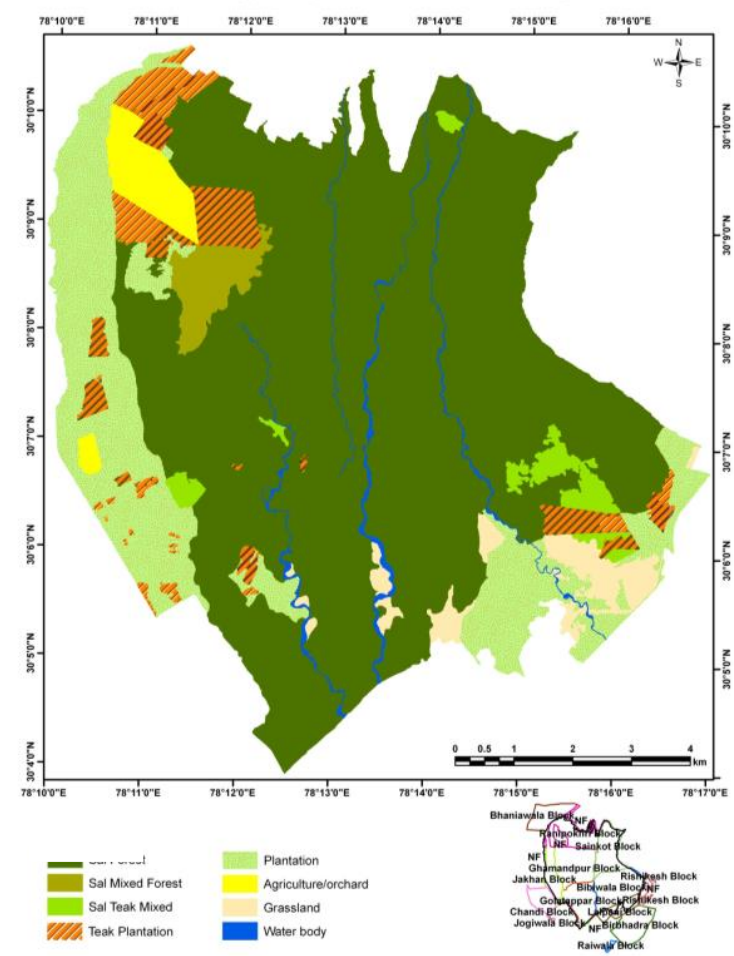

(b)

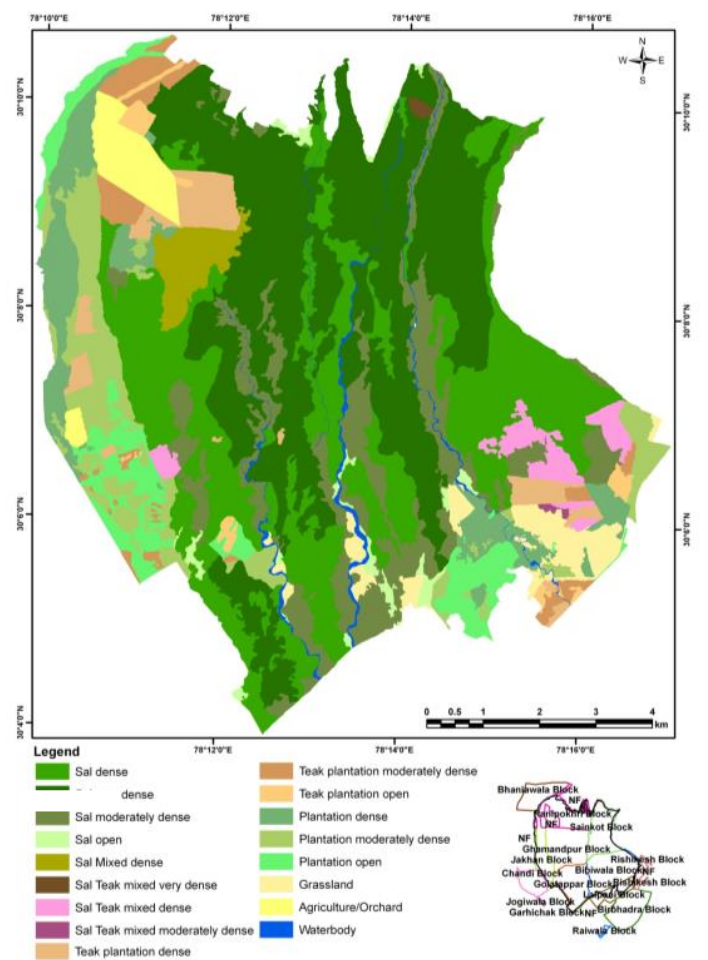

(d)

Fig. 3 (a). FCC of study area, (b). Forest/land use map, (c). Crown density map and, (d). Forest type-density strata map 
Table 2. Growing stock, biomass and carbon in different forest stratum.

\begin{tabular}{|c|c|c|c|c|c|c|c|}
\hline S. No. & Stratum & $\begin{array}{l}\text { Mean } \\
\text { volume } \\
\left(\mathrm{m}^{3} / \mathrm{ha}\right)\end{array}$ & $\begin{array}{l}\text { Total GS } \\
\left(\mathrm{m} 3 * 10^{3}\right)\end{array}$ & $\begin{array}{l}\text { Mean } \\
\text { biomass } \\
(\mathrm{t} / \mathrm{ha})\end{array}$ & $\begin{array}{l}\text { Total } \\
\text { biomass } \\
\left(\mathrm{t}^{*} 10^{3}\right)\end{array}$ & $\begin{array}{l}\text { Mean } \\
\text { carbon } \\
(\mathrm{t} / \mathrm{ha})\end{array}$ & $\begin{array}{l}\text { Total } \\
\text { carbon } \\
\left(\mathrm{t}^{*} 10^{3}\right)\end{array}$ \\
\hline 1 & S.robusta $(>70 \%)$ & 626.67 & 1573.26 & 530.08 & 1330.79 & 249.14 & 625.47 \\
\hline 2 & S.robusta $(40-70 \%)$ & 583.01 & 1187.03 & 486.54 & 990.61 & 228.67 & 465.59 \\
\hline 3 & S.robusta $(10-40 \%)$ & 511.46 & 484.33 & 393.00 & 372.15 & 184.71 & 174.91 \\
\hline 4 & S.robusta $(<10 \%)$ & 231.75 & 22.27 & 199.90 & 19.21 & 93.97 & 9.03 \\
\hline 5 & S.robusta mixed (40-70\%) & 506.97 & 168.99 & 372.99 & 124.33 & 175.32 & 58.44 \\
\hline 6 & S.robusta T. grandis $(>70 \%)$ & 575.42 & 5.76 & 486.51 & 4.87 & 228.77 & 2.29 \\
\hline 7 & S.robusta $T$. grandis $(40-70 \%)$ & 527.65 & 89.79 & 435.15 & 74.05 & 204.50 & 34.80 \\
\hline 8 & S.robusta T. grandis (10-40\%) & 352.98 & 2.12 & 314.68 & 1.89 & 148.18 & 0.89 \\
\hline 9 & T. grandis $(40-70 \%)$ & 410.00 & 99.32 & 359.60 & 87.11 & 169.00 & 40.94 \\
\hline 10 & T. grandis $(10-40 \%)$ & 311.94 & 63.70 & 272.27 & 55.60 & 127.96 & 26.13 \\
\hline 11 & T. grandis $(<10 \%)$ & 126.90 & 10.67 & 200.87 & 16.89 & 94.43 & 7.94 \\
\hline 12 & Mixed Plantation (40-70\%) & 299.65 & 120.88 & 248.96 & 100.43 & 117.00 & 47.20 \\
\hline 13 & Mixed Plantation (10-40\%) & 253.83 & 123.74 & 214.49 & 104.56 & 100.80 & 49.14 \\
\hline 14 & Mixed Plantation $(<10 \%)$ & 104.72 & 44.34 & 101.34 & 42.91 & 47.64 & 20.17 \\
\hline
\end{tabular}

Different regression models were established between estimated AGB obtained from ground observations and corresponding NDVI values and with different spectral bands. Strong correlation, with $R^{2}$ value of 0.71 was noticed between NDVI and biomass. The regression model, so generated, was used for computation of biomass and carbon for the entire study area (Fig. 4a). The fieldestimated and predicted values for biomass showed $77 \%$ agreement at $96 \%$ confidence level $(\mathrm{N}=30)$ (Fig. 4b), which indicates that NDVI can be used for estimation of the biomass. The maximum above ground carbon density was found in Sal with very high density and minimum in low density class. The maximum AGB was found in sal $>70 \%$ $\left(530 \mathrm{t} \mathrm{ha}^{-1}\right)$, followed by sal $40-70 \%\left(486 \mathrm{t} \mathrm{ha}^{-1}\right)$ and minimum was found in mixed plantation $<10 \%\left(101 \mathrm{t} \mathrm{ha}^{-1}\right)$. As expected, the tree layer of total above ground carbon has the major contribution among all components, varies from $97 \%$ to $99 \%$ of the total above ground carbon. The carbon density in tree layer showed decreasing trend with decrease of forest density classes similar to total above ground and tree layer was most adversely affected by forest degradation. Below ground carbon was estimated only for tree layer based on root/shoot ratio and therefore the results were also similar to tree layer.

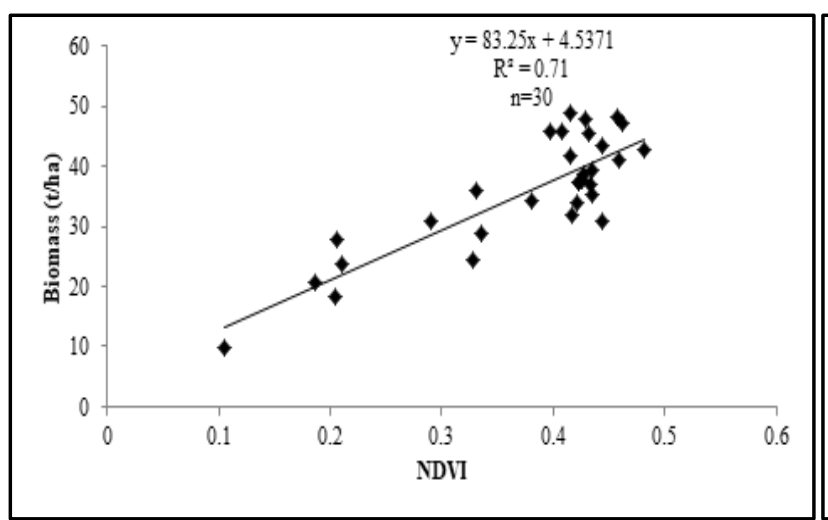

(a)

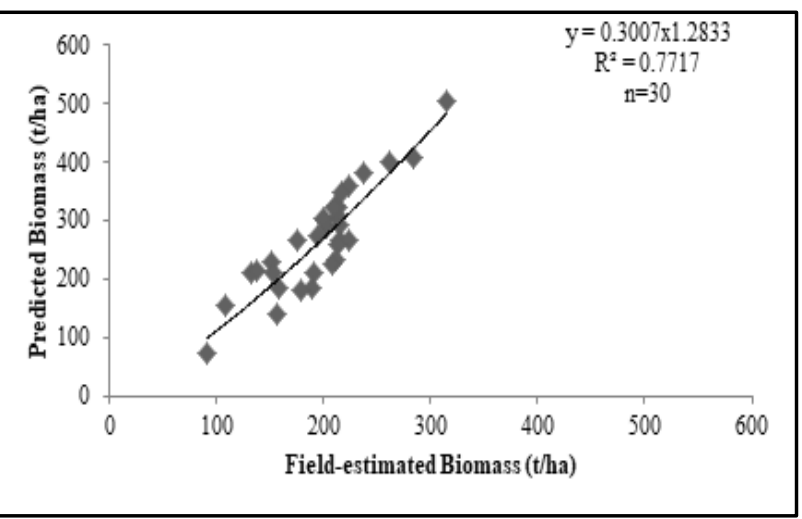

(b)

Fig. 4. Correlation between (a). NDVI and biomass and (b). predicted and field estimated biomass 


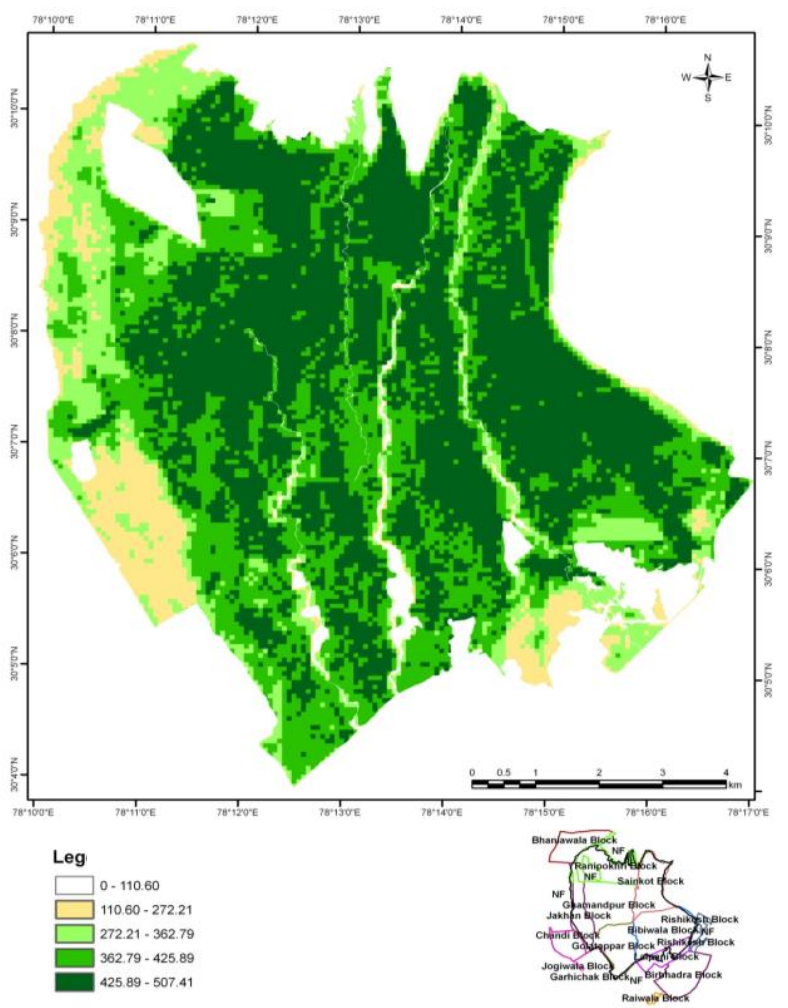

(b)

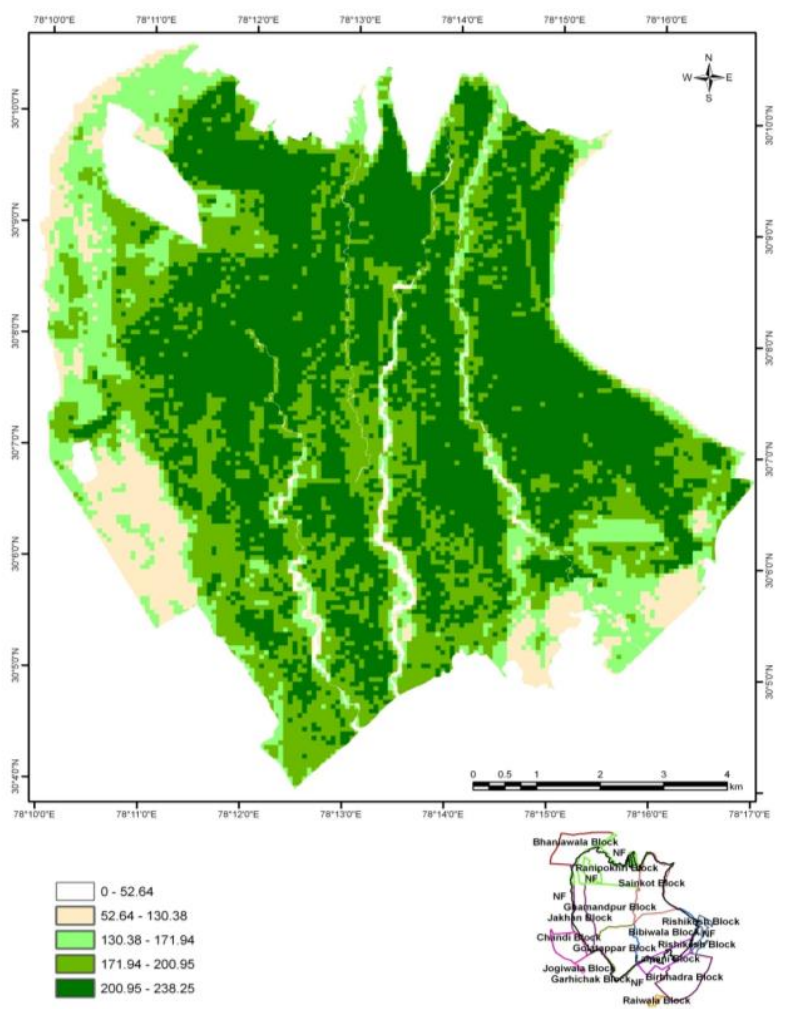

(b)

Fig. 5a Biomass and $\mathbf{b}$ Carbon in Barkot Forest Range

\section{Conclusion}

The highest potential carbon density was assessed for pure Sal followed by Sal mixed, Sal teak and teak plantation, indicating that pure Sal forests are better in carbon sequestration in the present study area. The best fit regression correlation of estimated aboveground biomass carbon was found with NDVI values of linear function. The results of above ground biomass and carbon mapping was validated which indicates good prediction with the model developed. It may be conclude from the present study that pure Sal forest is better in C-sequestration. The present data can be used as baseline information for further temporal studies to ascertain the status of carbon sequestration in Sal forest and planning of forest management plan to address the problem of forest degradation to enrich the carbon sequestration and long term carbon stock as mitigation

\section{REFERENCES}

Anonymous, 2009. Working Plan of Dehradun Forest Division. Part-I (2009-2018), Govt. of Uttarakhand, pp180.

Cairns, M.A., Brown, S., Helmer, E.M., Baumgardener, G.A. 1997. Root biomass allocation in the world's upland forest. Oecologia, 111: 1-11.

Cochran, W.G. 1963. Sampling Techniques. John Wiley \& Sons, Inc., New York.

Chacko, V. J. 1965. A Manual on Sampling Techniques for Forest Surveys. The Manager of Publications, Delhi. 172 p.

Dadhwal, V.K., Kushwaha, S.P.S., Singh, I.J., Nandy, S., Mukhtopadhyay, S., Pandey, U. 2006. Understanding terrestrial carbon cycle in India using remote sensing. Proc. measures of global warming. The use of alternative imaging technology (SAR, LiDAR, or high resolution imagery) be considered and methods to better capture the horizontal (spatial) and vertical (height) characteristics of the forest should be further studied.

\section{ACKNOWLEDGMENTS}

The authors wish to thank the Director of the Indian Institute of Remote Sensing, Indian Space Research Organization, Dehradun, for the encouragement and support for this study. Grateful thanks are due to the Divisional Forest Officer, Dehradun Forest Division, and staff of Barkot Forest Range, Dehradun Forest Division, Government of Uttarakhand, India, for field support.

Indo-UK workshop on earth observations for weather and climate, March 28-30, 2006, SAC, Ahmedabad.

Dube T., Mutanga O., Shoko C., Samuel A. \& Bangira T. 2016. Remote sensing of aboveground forest biomass: A review. Tropical Ecology 57(2): 125-132.

Galidaki, G., Zianis, D., Gitas, I., Radoglou, K., Karathanassi, V., Tsakiri-Strati, M., Mallinis, G. 2016. Vegetation biomass estimation with remote sensing: focus on forest and other wooded land over the Mediterranean ecosystem. International Journal of Remote Sensing, 38(7), 1940-1966.

FAO, 2010. State of the World's Forests, Rome.

FAO, 2012. Forests and Climate Change Working Paper 10 Forest Management and Climate Change: a literature 
review. Food and Agriculture Organization of the United Nations, Rome.

Forest Survey of India (FSI), 1996. Volume equations for Forests of India, Nepal \& Bhutan, Ministry of Environment \& Forests, Govt. of India.

FRA, 2015. The Global Forest Resources Assessment 2015 - How are the world's forests changing? Second edition.

IPCC, 2007: Summary for Policymakers. In: Climate Change 2007: The Physical Science Basis. Contribution of Working Group I to the Fourth Assessment Report of the Intergovernmental Panel on Climate Change [Solomon, S., D. Qin, M. Manning, Z. Chen, M. Marquis, K.B. Averyt, M.Tignor and H.L. Miller (eds.)]. Cambridge University Press, Cambridge, United Kingdom and New York, NY, USA.

Fern, R. R., Foxley, E. A., Bruno, A., \& Morrison, M. L. 2018. Suitability of NDVI and OSAVI as estimators of green biomass and coverage in a semi-arid rangeland. Ecological Indicators, 94, 16-21.

FSI, 2017. India State of Forest Report 2017. Dehradun: Forest Survey of India, Ministry of Environment and Forests, Government of India.

John, R., Chen, J., Giannico, V., Park, H., Xiao, J., Shirkey, G., Qi, J. 2018. Grassland canopy cover and aboveground biomass in Mongolia and Inner Mongolia: Spatiotemporal estimates and controlling factors. Remote Sensing of Environment, 213, 34-48.

Kira, T. and Ogawa, H. 1971. Assessment of primary production in tropical forests, Proc. Productivity of Forest Ecosystems, Brussels-1969, UNESCO Publication.

Kushwaha, S.P.S., Singh, I.J. and Paul, S. 2003. Comparison of sampling methods for inventorying the stand volume using satellite remote sensing. Journal of the Indian Society of Remote Sensing, 31(4): 283-290.

Kushwaha, S.P.S. 2005. Geospatial technology for forest resources management. International Journal of Remote Sensing, 31(1): 9-20.

Kushwaha S.P.S. Nandy S. and Gupta M. 2014. Growing stock and woody biomass in Asola-Bhati Wildlife Sanctuary, Delhi, India, Environ Monit Assess, 186 (9), pp 5911-5920.

Lal, A.K., Singh, P.P. 2003. Economic worth of carbon stored in above ground biomass of India's forests, Indian Forester 129(7): 874-880.

Lillesand T., Kiefer Ralph W, Jonathan Chipman J. 2007. Remote Sensing and Image Interpretation, 6th Edition, ISBN: 978-0-470-05245-7.

Liviu T. E. et al. 2017. Remote Sensing of Environment. 188: 106-117.

Lu, X. T., J. X. Yin, M. R. Jepsen \& J. W. Tang. 2010. Ecosystem carbon storage and partioning in a tropical seasonal forest in Southwestern China. Forest Ecology and Management 260: 1798-1803.

MEA-Millennium Ecosystem Assessment 2005. 'Chapter 21: Forests and woodland systems' in: MA Ecosystems and Well-being: Current State and Trends, Island Press, Washington DC: 605.
Misra, R. 1969 Studies on the primary productivity of terrestrial communities at Varanasi. Trop. Ecol. 10, 1-15.

Mohd Zaki, N. A., Latif, Z. A., \& Suratman, M. N. 2018. Modelling above-ground live trees biomass and carbon stock estimation of tropical lowland Dipterocarp forest: integration of field-based and remotely sensed estimates. International Journal of Remote Sensing, 39(8): 2312 2340 .

Negi, J.D.S. 1984. Biological productivity and cycling of nutrients in managed and man-made ecosystems. Ph.D. Thesis, Garhwal university, Forest Research Institute and College, New Forest, Dehradun.

Negi, J.D.S., Chauhan, P.S. 2002. Green house gases mitigation potential by Sal (Shorea robusta Garten F.) forests in doon valley. Indian Forester, 128(7): 771-778.

Ollinger, S.C., Goodale, Hayhoe, K. and Jenkins, J.P. 2008. Potential effects of climate change and rising $\mathrm{CO}_{2}$ on ecosystem processes in northeastern U.S. forests. Mitigation and Adaptation Strategies for Global Change, 13 (5): 467-485

Pandey, U., Kushwaha S.P.S., Kachhwaha, T.S., Kunwar, P., \& and Dadhwal, V.K. 2010. Potential of Envisat ASAR data for woody biomass assessment. Tropical Ecology, 51(1): 117-124, 2010.

Pedro R.-V., James W., Valentin L., Kevin T. \& Heiko B. 2017. Quantifying Forest Biomass Carbon Stocks from Space. Curr Forestry Rep. 3:1-18.

Qureshi, A., B. R. Pariva \& S. A. Hussain.2012. A review of protocols used for assessment of carbon stock in forested landscapes. Ennvironmental Science and Policy 16: 81-89.

Pandey, U., Kushwaha S.P.S., Kachhwaha, T.S., Kunwar, P., \& and Dadhwal, V.K. 2010. Potential of Envisat ASAR data for woody biomass assessment. Tropical Ecology, 51(1): 117-124, 2010.

Singh, S.P. 2010. Impact of Forest Degradation on Carbon Density in Soil and Vegetation of Shorea robusta (Sal) Forests in the part of Siwalik hills of Dehradun, India, using Geospatial Techniques. M.Sc. Thesis, International Institute for Geo-information Science and Earth Observation, Enschede, The Netherland.

Srivastava, M.L., 2009. Geospatial analysis of productivity and biomass dynamics using remote sensing and geographical information system. M.Tech. thesis, IIRS, Dehradun, India.

Nandy, S., Singh, R., Ghosh, S., Watham, T., Kushwaha, S. P. S., Kumar, A. S., \& Dadhwal, V. K. 2017. Neural network-based modelling for forest biomass assessment. Carbon Management, 8(4), 305-317.

Valentin B. and Sebastiaan L., 2014. Nature 506, 153-155.

Westlake, D. F., 1963. Comparisons of plant productivity. Biol, Rev. 38:385-425.

Whitehead, D., 2011. Forests as carbon sinks—benefits and consequences, Tree Physiology, 31(9): 893-902.

Working Plan of Dehradun forest division, Dehradun (Shiwalik Circle). Part - II, Vol. III, 2009-10 - 2018-19. 